NASA/TM-2000-209891, Vol. 194

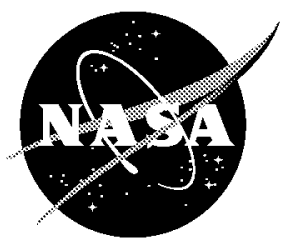

Technical Report Series on the Boreal Ecosystem-Atmosphere Study (BOREAS)

Forrest G. Hall and Karl Huemmrich, Editors

\title{
Volume 194
}

BOREAS TF-2 SSA-OA Tethersonde Meteorological and Ozone Data

A. James Arnold and Robert E. Mickle

Atmospheric Environment Service, Downsview, Ontario

National Aeronautics and

Space Administration

Goddard Space Flight Center

Greenbelt, Maryland 20771 
The NASA STI Program Office ... in Profile

Since its founding, NASA has been dedicated to the advancement of aeronautics and space science. The NASA Scientific and Technical Information (STI) Program Office plays a key part in helping NASA maintain this important role.

The NASA STI Program Office is operated by Langley Research Center, the lead center for NASA's scientific and technical information. The NASA STI Program Office provides access to the NASA STI Database, the largest collection of aeronautical and space science STI in the world. The Program Office is also NASA's institutional mechanism for disseminating the results of its research and development activities. These results are published by NASA in the NASA STI Report Series, which includes the following report types:

- TECHNICAL PUBLICATION. Reports of completed research or a major significant phase of research that present the results of NASA programs and include extensive data or theoretical analysis. Includes compilations of significant scientific and technical data and information deemed to be of continuing reference value. NASA's counterpart of peer-reviewed formal professional papers but has less stringent limitations on manuscript length and extent of graphic presentations.

- TECHNICAL MEMORANDUM. Scientific and technical findings that are preliminary or of specialized interest, e.g., quick release reports, working papers, and bibliographies that contain minimal annotation. Does not contain extensive analysis.

- CONTRACTOR REPORT. Scientific and technical findings by NASA-sponsored contractors and grantees.
- CONFERENCE PUBLICATION. Collected papers from scientific and technical conferences, symposia, seminars, or other meetings sponsored or cosponsored by NASA.

- SPECIAL PUBLICATION. Scientific, technical, or historical information from NASA programs, projects, and mission, often concerned with subjects having substantial public interest.

- TECHNICAL TRANSLATION. English-language translations of foreign scientific and technical material pertinent to NASA's mission.

Specialized services that complement the STI Program Office's diverse offerings include creating custom thesauri, building customized databases, organizing and publishing research results ... even providing videos.

For more information about the NASA STI Program Office, see the following:

- Access the NASA STI Program Home Page at http://www.sti.nasa.gov/STI-homepage.html

- E-mail your question via the Internet to help@sti.nasa.gov

- Fax your question to the NASA Access Help Desk at (301) 621-0134

- Telephone the NASA Access Help Desk at (301) 621-0390

- Write to:

NASA Access Help Desk

NASA Center for AeroSpace Information 7121 Standard Drive Hanover, MD 21076-1320 
NASA/TM-2000-209891, Vol. 194

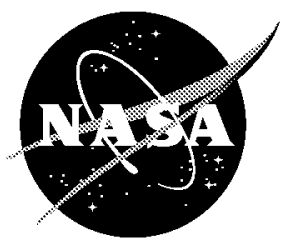

Technical Report Series on the Boreal Ecosystem-Atmosphere Study (BOREAS)

Forrest G. Hall and Karl Huemmrich, Editors

\section{Volume 194}

BOREAS TF-2 SSA-OA Tethersonde Meteorological and Ozone Data

A. James Arnold and Robert E. Mickle

Atmospheric Environment Service, Downsview, Ontario

National Aeronautics and

Space Administration

Goddard Space Flight Center

Greenbelt, Maryland 20771 


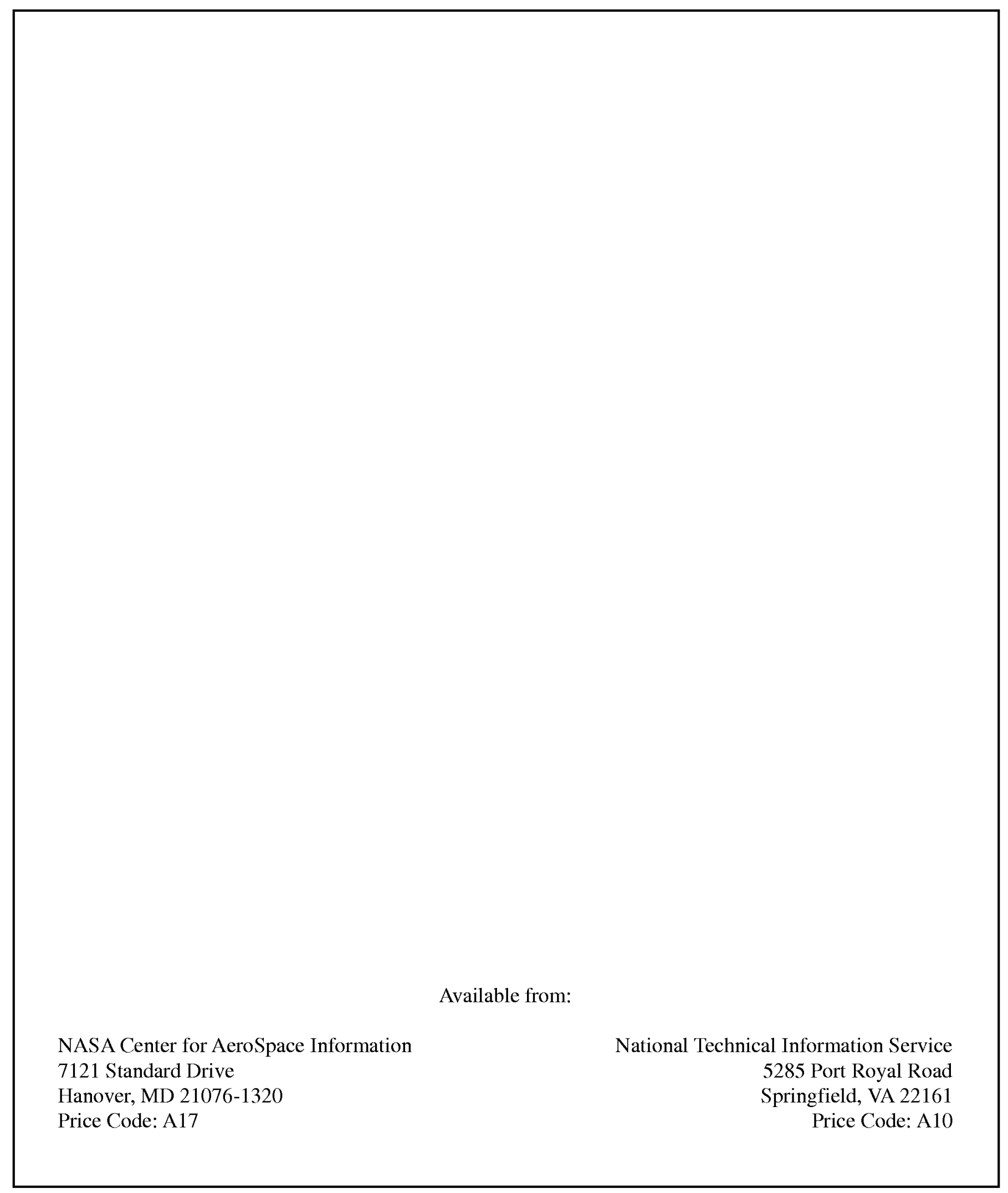




\title{
BOREAS TF-2 SSA-OA Tethersonde Meteorological and Ozone Data
}

\author{
A. James Arnold, Robert E. Mickle
}

\section{Summary}

The BOREAS TF-2 team collected meteorological and ozone measurements from instruments mounted below a tethered balloon. These data were collected at the SSA-OA site to extend meteorological and ozone measurements made from the flux tower to heights of $300 \mathrm{~m}$. The tethersonde operated during the fall of 1993 and the spring, summer, and fall of 1994. The data are available in tabular ASCII files.

\section{Table of Contents}

1) Data Set Overview

2) Investigator(s)

3) Theory of Measurements

4) Equipment

5) Data Acquisition Methods

6) Observations

7) Data Description

8) Data Organization

9) Data Manipulations

10) Errors

11) Notes

12) Application of the Data Set

13) Future Modifications and Plans

14) Software

15) Data Access

16) Output Products and Availability

17) References

18) Glossary of Terms

19) List of Acronyms

20) Document Information

\section{Data Set Overview}

\subsection{Data Set Identification \\ BOREAS TF-02 SSA-OA Tethersonde Meteorological and Ozone Data}

\subsection{Data Set Introduction}

A tethersonde program was carried out at the BOReal Ecosystem-Atmosphere Study (BOREAS) Southern Study Area (SSA) Old Aspen (OA) site to extend meteorological and ozone measurements made from the flux tower to heights of $300 \mathrm{~m}$. Launched from a clearing approximately $100 \mathrm{~m}$ from the main tower, an Atmospheric Instrumentation Research (AIR) tethersonde package was mounted below a $25-\mathrm{m}^{3}$ tethered balloon and profiled during selected periods of the field experiment. For most of the profiles, a Mast-Brewer ozone sonde was coupled to the tethersonde. Data were collected in the fall of 1993 and during the Intensive Field Campaigns (IFCs) of 1994.

\subsection{Objective/Purpose}

The purpose of this study was to characterize the atmosphere's vertical structure in terms of air pressure, temperature, humidity, winds, and ozone concentration to complement and extend the data being collected from the SSA-OA flux tower and flux aircraft. 


\subsection{Summary of Parameters and Variables}

From the tethersonde, vertical profiles of air temperature, potential temperature, relative humidity, air pressure, wind speed and direction, and ozone concentration were collected. Measurements were located along the profiles by the height above ground level.

\subsection{Discussion}

This study measured high-resolution vertical profiles of temperature, humidity, pressure, wind speed and direction, and ozone concentration in the lower atmospheric boundary layer. An AIR tethersonde package (TS-3A-SP) was mounted below a $25 \mathrm{~m}^{3}$ tethered balloon and profiled during selected periods of the field experiment. For most of the profiles, a Mast-Brewer ozone sonde (AIR OZ-3A-T) was coupled to the tethersonde. The tethersonde was raised and lowered using a heavy-duty winch.

\subsection{Related Data Sets}

BOREAS TF-02 SSA-OA Tower Flux and Meteorological Data

BOREAS TF-01 SSA-OA Undercanopy Flux, Meteorological, and Snow/Soil Temp Data

\section{Investigator(s)}

\subsection{Investigator(s) Name and Title}

Robert E. Mickle

Atmospheric Environment Service

A. James Arnold

Atmospheric Environment Service

\subsection{Title of Investigation}

AES Flux Tower Measurements for BOREAS: Exchange of Energy, Water Vapor, and Trace Gases Project

\subsection{Contact Information}

\section{Contact 1:}

A. James Arnold

Atmospheric Environment Service

4905 Dufferin Street

Downsview, Ontario M3H 5T4

Canada

(416) 739-4855

(416) 739-4293 (fax)

jim.arnold@ec.gc.ca

\section{Contact 2:}

Robert E. Mickle

Atmospheric Environment Service

4905 Dufferin Street

Downsview, Ontario M3H 5T4

Canada

REMSpC@golden.net 


\section{Contact 3:}

K. Fred Huemmrich

University of Maryland

Code 923

NASA GSFC

Greenbelt, MD 20771

(301) 286-4862

(301) 286-0239 (fax)

Karl.Huemmrich@gsfc.nasa.gov

\section{Theory of Measurements}

A helium-filled balloon can lift instruments off of the ground and provides a stable platform for measurements at altitudes higher than can be reached by towers. Tethering the balloon allows control of the balloon's altitude and ensures retrieval of the attached instruments. The tether also lets one control the rates of ascent and descent. Because of these features, the tethersonde is able to provide high-resolution vertical profiles of the characteristics of the lower atmospheric boundary layer.

\section{Equipment}

\subsection{Sensor/Instrument Description}

\subsubsection{Collection Environment}

The tethersonde could not be launched under conditions of high wind speeds.

\subsubsection{Source/Platform}

Instruments were attached below a $25-\mathrm{m}^{3}$ tethered balloon. The tethersonde was launched from a clearing approximately $100 \mathrm{~m}$ from the SSA-OA flux tower. The tethersonde reached heights of 300 $\mathrm{m}$, and was raised and lowered using a heavy-duty winch.

\subsubsection{Source/Platform Mission Objectives}

The purpose of the tethersonde was to allow vertical profiles of atmospheric variables to be measured at heights greater than the flux tower.

\subsubsection{Key Variables}

Vertical profiles of air temperature, potential temperature, relative humidity, air pressure, wind speed and direction, and ozone concentration were collected. Measurements were located along the profiles by the height above ground level.

\subsubsection{Principles of Operation}

The tethersonde supported an AIR tethersonde package (TS-3A-SP). The sensors include dry and wet bulb thermistors, an aneroid capacitance barometer, a three-cup anemometer with tachometer, and a magnetic compass. Humidity was obtained using dry and wet bulb measurements and the psychometric equation. For most of the profiles a Mast-Brewer ozone sonde (AIR OZ-3A-T) was coupled to the tethersonde.

\subsubsection{Sensor/Instrument Measurement Geometry}

The instruments were suspended under a $25-\mathrm{m}^{3}$ balloon. The height of the measurements and the rate of ascent or descent were controlled by the winch on the ground. 


\subsubsection{Manufacturer of Sensor/Instrument}

Tethersonde package (TS-3A-SP) and ozone sonde (AIR OZ-3A-T):

AIR, Inc.

8401 Baseline Rd.

Boulder, CO 80303

(303) 499-1701

(303) 499-1767 (fax)

rons@airmfg.com

\subsection{Calibration}

\subsubsection{Specifications}

Factory calibrations for the meteorology package provided sensor precision of $0.5{ }^{\circ} \mathrm{C}$ for air temperature, 5 percent for relative humidity, $1 \mathrm{mb}$ for the aneroid barometer, $0.25 \mathrm{~m} / \mathrm{s}$ for wind speed, and $5^{\circ}$ for wind direction. Prior to and after each profile, the ozone sonde was calibrated against a Dasibi (Model 1008-RS) calibrator/analyzer to minimize drift due to cell aging. Calibrations were repeatable to within $3 \mathrm{ppb}$.

\subsubsection{Tolerance}

The wet and dry bulb thermistors operated over a range of 50 to $-70{ }^{\circ} \mathrm{C}$ with a precision of $0.5^{\circ} \mathrm{C}$ and a resolution of $0.01{ }^{\circ} \mathrm{C}$. The aneroid barometer operated over a range of 1050 to $600 \mathrm{mb}$ with a precision of $1 \mathrm{mb}$ and a resolution of $0.1 \mathrm{mb}$. The anemometer measured wind speed over the range 0 to $20 \mathrm{~m} / \mathrm{s}$ with a precision of $0.25 \mathrm{~m} / \mathrm{s}$ and a resolution of $0.01 \mathrm{~m} / \mathrm{s}$. The wind direction was measured over a range of 2 to $358^{\circ}$ with a precision of $5^{\circ}$ and a resolution of $1^{\circ}$.

\subsubsection{Frequency of Calibration}

Prior to and after each profile, the ozone sonde was calibrated against a Dasibi (Model 1008-RS ) calibrator/analyzer to minimize drift due to cell aging.

\subsubsection{Other Calibration Information}

None.

\section{Data Acquisition Methods}

Launched from a clearing approximately $100 \mathrm{~m}$ from the main tower, an AIR tethersonde package was mounted below a $25 \mathrm{~m}^{3}$ tethered balloon and profiled during selected periods of the field experiment. The height of the measurements and the rate of ascent or descent were controlled by the winch on the ground. The tethersonde could not be launched under conditions of high wind speeds.

\section{Observations}

\subsection{Data Notes}

None.

\subsection{Field Notes \\ None.}




\section{Data Description}

\subsection{Spatial Characteristics}

\subsubsection{Spatial Coverage}

All data were collected at the BOREAS SSA-OA site. The tethersonde was launched from a clearing $100 \mathrm{~m}$ from the flux tower. The North American Datum of 1983 (NAD83) coordinates for the SSA-OA flux tower are latitude $53.62889^{\circ} \mathrm{N}$, longitude $106.19779^{\circ} \mathrm{W}$, and elevation of $600.63 \mathrm{~m}$.

\subsubsection{Spatial Coverage Map}

Not available.

\subsubsection{Spatial Resolution}

The spatial resolution of the measurements is dependent on sonde height and atmospheric conditions.

\subsubsection{Projection}

Not applicable.

\subsubsection{Grid Description}

Not applicable.

\subsection{Temporal Characteristics}

\subsubsection{Temporal Coverage}

Data were collected in 1993 from 17-Oct to 31-Oct. In 1994, data were collected during the periods of 26-May to 12-Jun, 21-Jul to 09-Aug, and 31-Aug to 19-Sep, corresponding to the IFCs.

\subsubsection{Temporal Coverage Map}

None.

\subsubsection{Temporal Resolution}

Samples were collected at a rate of one every 10 seconds.

\subsection{Data Characteristics}

\subsubsection{Parameter/Variable}

The parameters contained in the data files on the CD-ROM are:

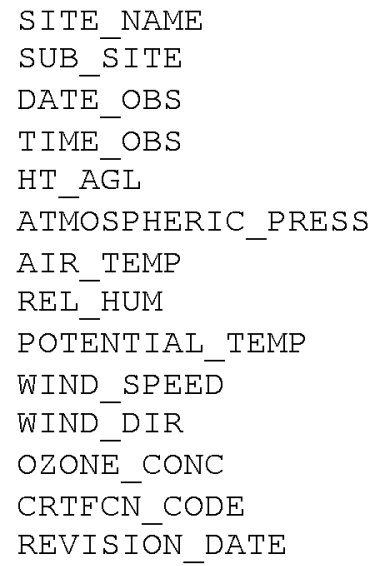




\subsubsection{Variable Description/Definition}

The descriptions of the parameters contained in the data files on the CD-ROM are:

\begin{tabular}{|c|c|}
\hline Column Name & Description \\
\hline SITE_NAME & $\begin{array}{l}\text { The identifier assigned to the site by BOREAS, in } \\
\text { the format SSS-TTT-CCCCC, where SSS identifies } \\
\text { the portion of the study area: NSA, SSA, REG, } \\
\text { TRN, and TTT identifies the cover type for the } \\
\text { site, } 999 \text { if unknown, and CCCCC is the identifier } \\
\text { for site, exactly what it means will vary with } \\
\text { site type. }\end{array}$ \\
\hline SUB_SITE & $\begin{array}{l}\text { The identifier assigned to the sub-site by BOREAS, } \\
\text { in the format GGGGG-IIIII, where GGGGG is the } \\
\text { group associated with the sub-site instrument, } \\
\text { e.g. HYD06 or STAFF, and IIIII is the identifier } \\
\text { for sub-site, often this will refer to an } \\
\text { instrument. }\end{array}$ \\
\hline DATE_OBS & The date on which the data were collected. \\
\hline TIME_OBS & $\begin{array}{l}\text { The Greenwich Mean Time (GMT) when the data were } \\
\text { collected. }\end{array}$ \\
\hline $\mathrm{HT}$ _AGL & $\begin{array}{l}\text { The height above ground at which the measurements } \\
\text { were taken. }\end{array}$ \\
\hline ATMOSPHERIC_PRESS & The atmospheric pressure. \\
\hline AIR_TEMP & The air temperature. \\
\hline REL_HUM & The calculated relative humidity. \\
\hline POTENTIAL_TEMP & The measured potential temperature. \\
\hline WIND_SPEED & The wind speed. \\
\hline WIND_DIR & $\begin{array}{l}\text { The direction from which the wind was traveling, } \\
\text { increasing in a clockwise direction from north. }\end{array}$ \\
\hline OZONE_CONC & The ozone concentration. \\
\hline CRTFCN_CODE & $\begin{array}{l}\text { The BOREAS certification level of the data. } \\
\text { Examples are CPI (Checked by PI), CGR (Certified } \\
\text { by Group), PRE (Preliminary), and CPI-??? (CPI but } \\
\text { questionable). }\end{array}$ \\
\hline REVISION_DATE & $\begin{array}{l}\text { The most recent date when the information in the } \\
\text { referenced data base table record was revised. }\end{array}$ \\
\hline
\end{tabular}

\subsubsection{Unit of Measurement}

The measurement units for the parameters contained in the data files on the CD-ROM are:

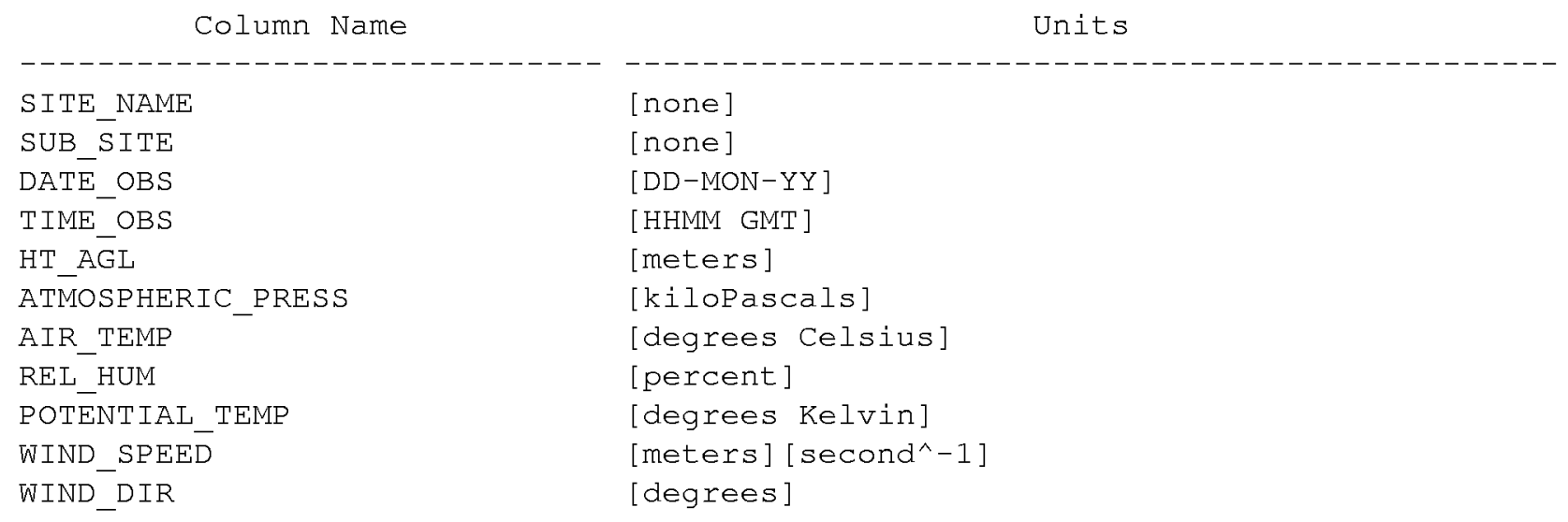


OZONE_CONC

CRTFCN CODE

REVISION_DATE [parts per billion]

[none]

[DD-MON-YY]

\subsubsection{Data Source}

The sources of the parameter values contained in the data files on the CD-ROM are:

\begin{tabular}{|c|c|}
\hline Column Name & Data Source \\
\hline SITE NAME & [Assigned by BORIS.] \\
\hline SUB_SITE & [Assigned by BORIS.] \\
\hline DATE_OBS & [Supplied by Investigator.] \\
\hline TIME_OBS & [Supplied by Investigator.] \\
\hline $\mathrm{HT} \_\mathrm{AGL}$ & [measurement of cable] \\
\hline ATMOSPHERIC_PRESS & [aneroid capacitance barometer] \\
\hline AIR_TEMP & [dry bulb thermistor] \\
\hline REL_HUM & [dry and wet bulb thermistors] \\
\hline POTENTIAL_TEMP & [dry and wet bulb thermistors] \\
\hline WIND_SPEED & [cup anemometer] \\
\hline WIND_DIR & [windvane] \\
\hline OZONE_CONC & [Mast-Brewer ozone sonde] \\
\hline CRTECN_CODE & [Assigned by BORIS.] \\
\hline REVISION_DATE & [Assigned by BORIS.] \\
\hline
\end{tabular}

\subsubsection{Data Range}

The following table gives information about the parameter values found in the data files on the CD-ROM.

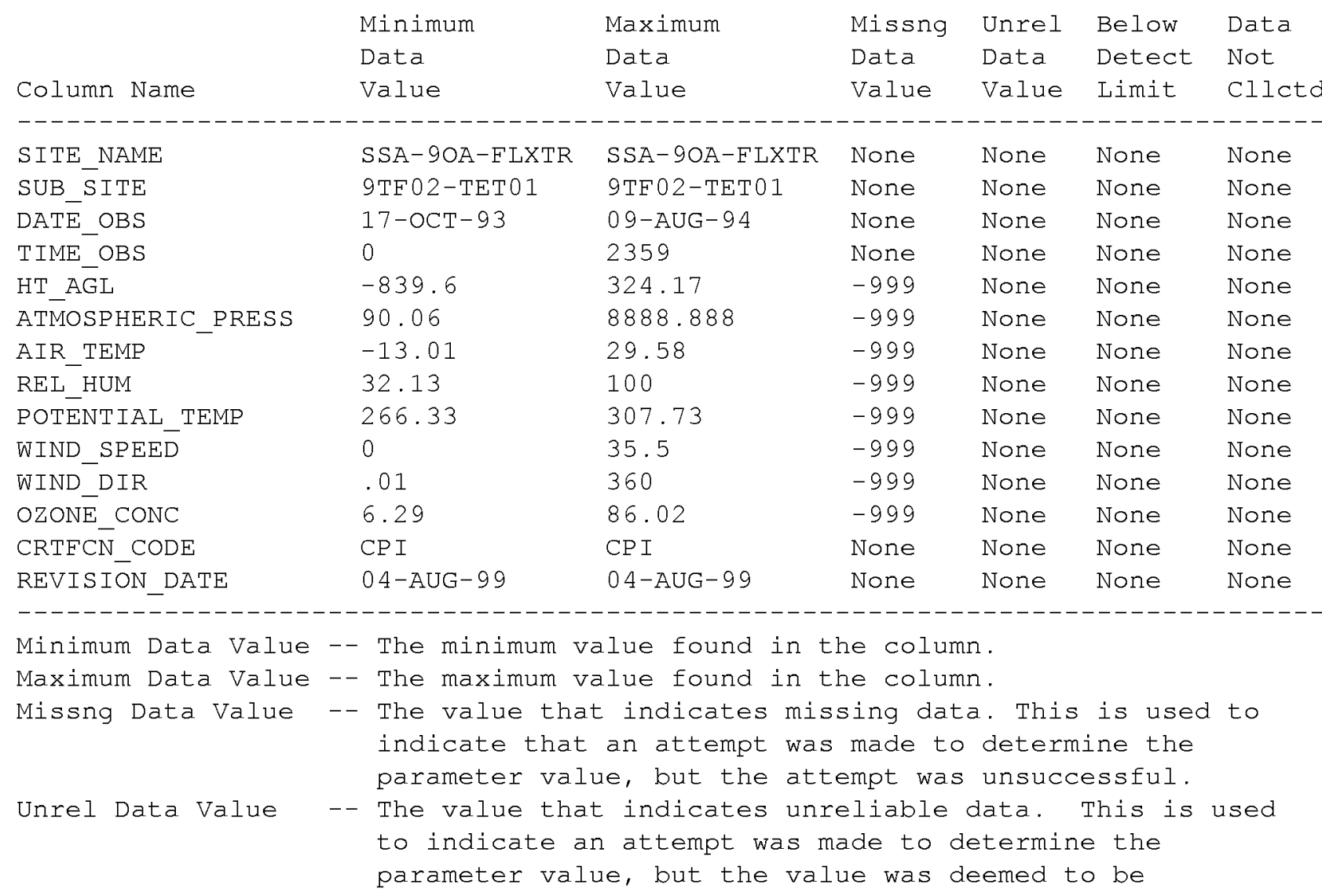




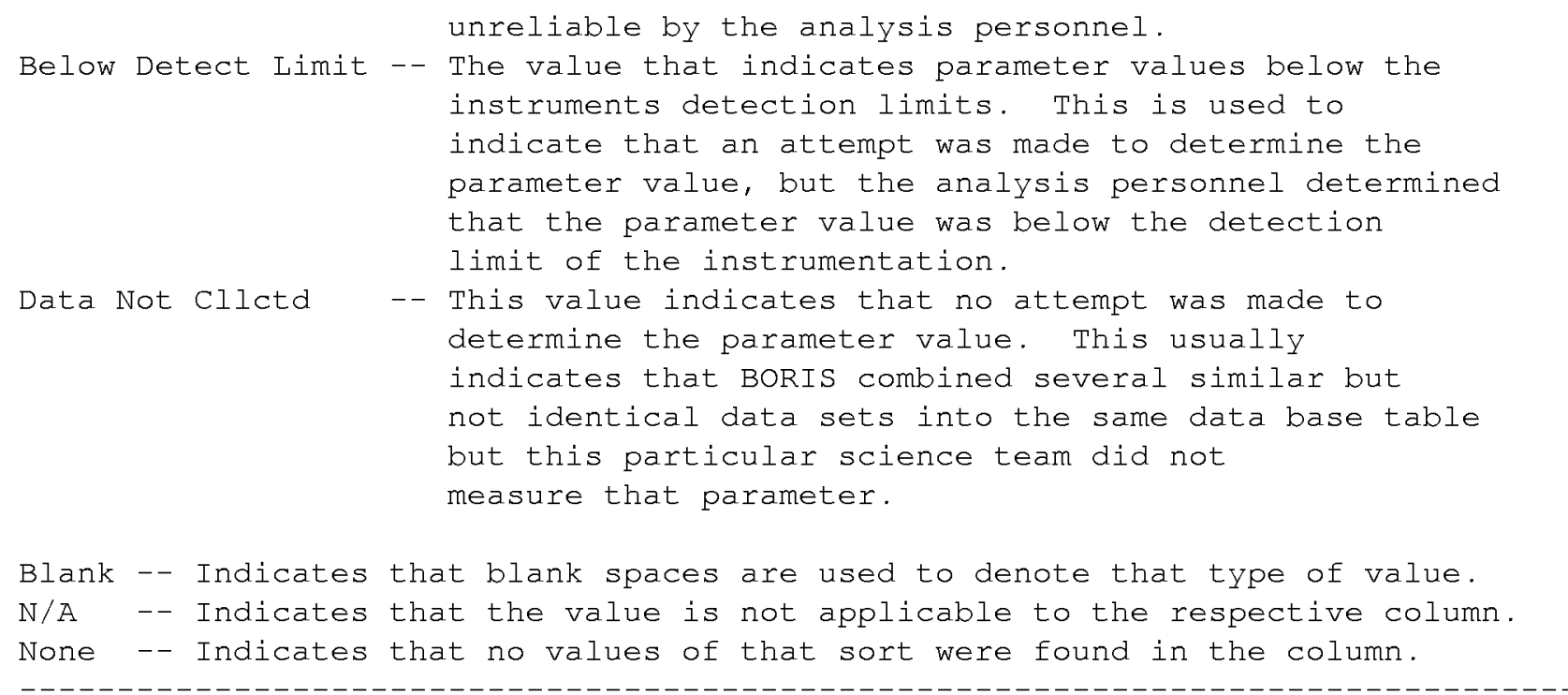

\subsection{Sample Data Record}

The following are wrapped versions of data records from a sample data file on the CD-ROM.

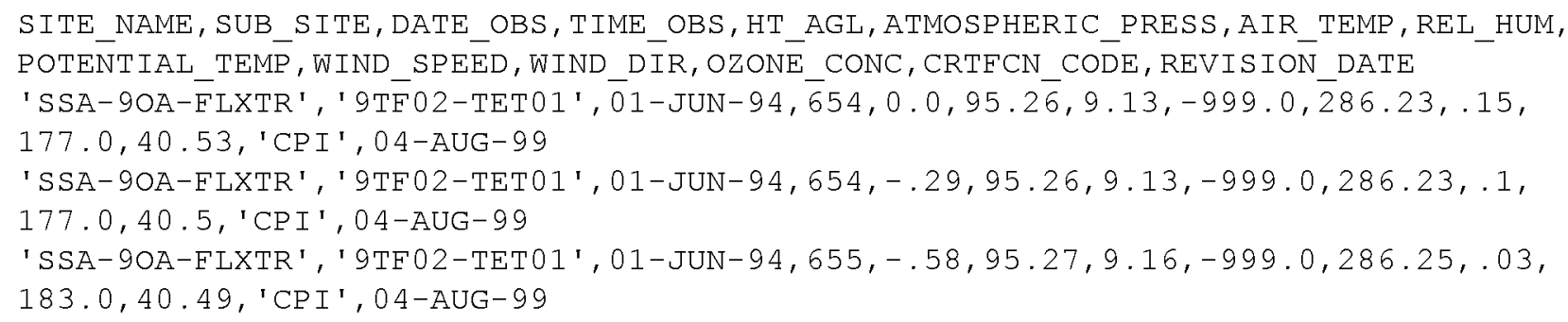

\section{Data Organization}

\subsection{Data Granularity}

The smallest unit of data tracked by the BOREAS Information System (BORIS) was data collected at a given site on a given date.

\subsection{Data Format}

The Compact Disk-Read-Only Memory (CD-ROM) files contain American Standard Code for Information Interchange (ASCII) numerical and character fields of varying length separated by commas. The character fields are enclosed with single apostrophe marks. There are no spaces between the fields.

Each data file on the CD-ROM has four header lines of Hyper-Text Markup Language (HTML) code at the top. When viewed with a Web browser, this code displays header information (data set title, location, date, acknowledgments, etc.) and a series of HTML links to associated data files and related data sets. Line 5 of each data file is a list of the column names, and line 6 and following lines contain the actual data. 


\section{Data Manipulations}

\subsection{Formulae}

\subsubsection{Derivation Techniques and Algorithms}

Humidity was obtained using dry and wet bulb measurements and the psychometric equation.

\subsection{Data Processing Sequence}

\subsubsection{Processing Steps}

BORIS staff processed these data by:

- $\quad$ Reviewing the initial data files and loading them online for BOREAS team access.

- Designing relational data base tables to inventory and store the data.

- $\quad$ Loading the data into the relational data base tables.

- Working with the team to document the data set.

- Extracting the data into logical files.

\subsubsection{Processing Changes}

None.

\subsection{Calculations}

\subsubsection{Special Corrections/Adjustments}

None given.

\subsubsection{Calculated Variables}

Humidity was obtained using dry and wet bulb measurements and the psychometric equation.

\subsection{Graphs and Plots}

None given.

\section{Errors}

\subsection{Sources of Error}

Prior to and after each profile, the ozone sonde was calibrated against a Dasibi (Model 1008-RS ) calibrator/analyzer to minimize drift due to cell aging.

\subsection{Quality Assessment}

\subsubsection{Data Validation by Source}

Data were examined by investigators to check for unreasonable values.

\subsubsection{Confidence Level/Accuracy Judgment}

None given.

\subsubsection{Measurement Error for Parameters}

The wet and dry bulb thermistors operated over a range of 50 to $-70{ }^{\circ} \mathrm{C}$ with a precision of $0.5^{\circ} \mathrm{C}$ and a resolution of $0.01{ }^{\circ} \mathrm{C}$. The aneroid barometer operated over a range of 1050 to $600 \mathrm{mb}$ with a precision of $1 \mathrm{mb}$ and a resolution of $0.1 \mathrm{mb}$. The anemometer measured wind speed over the range 0 to $20 \mathrm{~m} / \mathrm{s}$ with a precision of $0.25 \mathrm{~m} / \mathrm{s}$ and a resolution of $0.01 \mathrm{~m} / \mathrm{s}$. The wind direction was measured over a range of 2 to $358^{\circ}$ with a precision of $5^{\circ}$ and a resolution of $1^{\circ}$. 
10.2.4 Additional Quality Assessments

None.

\subsubsection{Data Verification by Data Center}

Data were examined to check for spikes, values that are four standard deviations from the mean, long periods of constant values, and missing data.

\section{Notes}

\subsection{Limitations of the Data}

The tethersonde could not be launched under conditions of high wind speeds.

\subsection{Known Problems with the Data} None given.

\subsection{Usage Guidance}

None given.

\subsection{Other Relevant Information}

None given.

\section{Application of the Data Set}

The data can be used for monitoring the development of the boundary layer and atmospheric movement and condition. In addition, the data can be used for comparisons with field studies occurring during respective IFCs.

\section{Future Modifications and Plans}

None.

\section{Software}

\subsection{Software Description}

None.

\subsection{Software Access}

None.

\section{Data Access}

The SSA-OA tethersonde meteorological and ozone data are available from the Earth Observing System Data and Information System (EOSDIS) Oak Ridge National Laboratory (ORNL) Distributed Active Archive Center (DAAC). 


\subsection{Contact Information}

For BOREAS data and documentation please contact:

ORNL DAAC User Services

Oak Ridge National Laboratory

P.O. Box 2008 MS-6407

Oak Ridge, TN 37831-6407

Phone: (423) 241-3952

Fax: (423) 574-4665

E-mail: ornldaac@ornl.gov or ornl@eos.nasa.gov

\subsection{Data Center Identification}

Earth Observing System Data and Information System (EOSDIS) Oak Ridge National Laboratory (ORNL) Distributed Active Archive Center (DAAC) for Biogeochemical Dynamics http://www-eosdis.ornl.gov/.

\subsection{Procedures for Obtaining Data}

Users may obtain data directly through the ORNL DAAC online search and order system [http://www-eosdis.ornl.gov/] and the anonymous FTP site [ftp://www-eosdis.ornl.gov/data/] or by contacting User Services by electronic mail, telephone, fax, letter, or personal visit using the contact information in Section 15.1.

\subsection{Data Center Status/Plans}

The ORNL DAAC is the primary source for BOREAS field measurement, image, GIS, and hardcopy data products. The BOREAS CD-ROM and data referenced or listed in inventories on the CD-ROM are available from the ORNL DAAC.

\section{Output Products and Availability}

\subsection{Tape Products}

None.

\subsection{Film Products}

None.

\subsection{Other Products}

These data are available on the BOREAS CD-ROM series.

\section{References}

\subsection{Platform/Sensor/Instrument/Data Processing Documentation \\ None.}

\subsection{Journal Articles and Study Reports}

Newcomer, J., D. Landis, S. Conrad, S. Curd, K. Huemmrich, D. Knapp, A. Morrell, J. Nickeson, A. Papagno, D. Rinker, R. Strub, T. Twine, F. Hall, and P. Sellers, eds. 2000. Collected Data of The Boreal Ecosystem-Atmosphere Study. NASA. CD-ROM.

Sellers, P. and F. Hall. 1994. Boreal Ecosystem-Atmosphere Study: Experiment Plan. Version 1994-3.0, NASA BOREAS Report (EXPLAN 94). 
Sellers, P. and F. Hall. 1996. Boreal Ecosystem-Atmosphere Study: Experiment Plan. Version 1996-2.0, NASA BOREAS Report (EXPLAN 96).

Sellers, P., F. Hall, and K.F. Huemmrich. 1996. Boreal Ecosystem-Atmosphere Study: 1994 Operations. NASA BOREAS Report (OPS DOC 94).

Sellers, P., F. Hall, and K.F. Huemmrich. 1997. Boreal Ecosystem-Atmosphere Study: 1996 Operations. NASA BOREAS Report (OPS DOC 96).

Sellers, P., F. Hall, H. Margolis, B. Kelly, D. Baldocchi, G. den Hartog, J. Cihlar, M.G. Ryan, B. Goodison, P. Crill, K.J. Ranson, D. Lettenmaier, and D.E. Wickland. 1995. The boreal ecosystem-atmosphere study (BOREAS): an overview and early results from the 1994 field year. Bulletin of the American Meteorological Society. 76(9):1549-1577.

Sellers, P.J., F.G. Hall, R.D. Kelly, A. Black, D. Baldocchi, J. Berry, M. Ryan, K.J. Ranson, P.M. Crill, D.P. Lettenmaier, H. Margolis, J. Cihlar, J. Newcomer, D. Fitzjarrald, P.G. Jarvis, S.T. Gower, D. Halliwell, D. Williams, B. Goodison, D.E. Wickland, and F.E. Guertin. 1997. BOREAS in 1997: Experiment Overview, Scientific Results and Future Directions. Journal of Geophysical Research 102(D24): 28,731-28,770.

\subsection{Archive/DBMS Usage Documentation}

None.

\section{Glossary of Terms}

None.

\section{List of Acronyms}

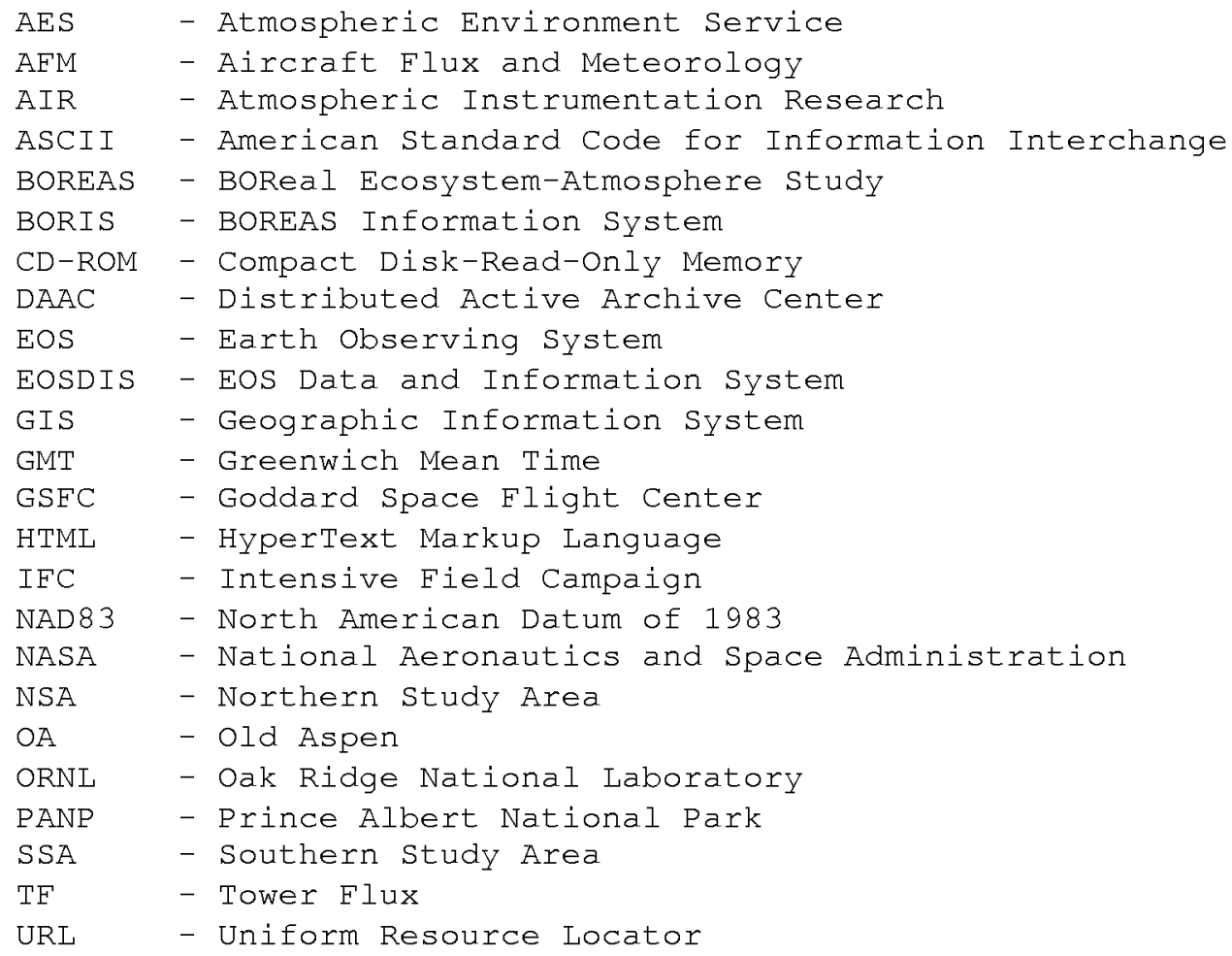




\section{Document Information}

20.1 Document Revision Date

Written: 26-May-1999

Revised: 08-Oct-1999

20.2 Document Review Date(s)

BORIS Review: 18-Aug-1999

Science Review:

\subsection{Document ID}

\subsection{Citation}

When using these data, please include the following acknowledgment as well as citations of relevant papers in Section 17.2:

Data were collected and processed by Robert E. Mickle and A. James Arnold of the Atmospheric Environment Service.

If using data from the BOREAS CD-ROM series, also reference the data as:

Mickle, R.E., A.J. Arnold, and G. den-Hartog, "AES Flux Tower Measurements for BOREAS:

Exchange of Energy, Water Vapor, and Trace Gases Project." In Collected Data of The Boreal

Ecosystem-Atmosphere Study. Eds. J. Newcomer, D. Landis, S. Conrad, S. Curd, K. Huemmrich, D. Knapp, A. Morrell, J. Nickeson, A. Papagno, D. Rinker, R. Strub, T. Twine, F. Hall, and P. Sellers. CD-ROM. NASA, 2000.

Also, cite the BOREAS CD-ROM set as:

Newcomer, J., D. Landis, S. Conrad, S. Curd, K. Huemmrich, D. Knapp, A. Morrell, J.

Nickeson, A. Papagno, D. Rinker, R. Strub, T. Twine, F. Hall, and P. Sellers, eds. Collected Data of The Boreal Ecosystem-Atmosphere Study. NASA. CD-ROM. NASA, 2000.

\subsection{Document Curator}

\subsection{Document URL}


Public reporting burden for this collection of information is estimated to average 1 hour per response, including the time for reviewing instructions, searching existing data sources, gathering and maintaining the data needed, and completing and reviewing the collection of information. Send comments regarding this burden estimate or any other aspect of this collection of information including suggestions for reducing this burden, to Washington Headquarters Services, Directorate for Information Operations and Reports, 1215 Jefferson Davis Highway, Suite 1204, Arlington, VA 22202-4302, and to the Office of Management and Budget, Paperwork Reduction Project (0704-0188), Washington, DC 20503.

\begin{tabular}{l|l|l}
\hline 1. AGENCY USE ONLY (Leave blank) & 2. REPORT DATE & 3. REPORT TYPE AND DATES COVERED
\end{tabular}

\begin{tabular}{l|l|l} 
October 2000 & Technical Memorandum
\end{tabular}

4. TITLE AND SUBTITLE

Technical Report Series on the Boreal Ecosystem-Atmosphere Study (BOREAS)

BOREAS TF-2 SSA-OA Tethersonde Meteorological and Ozone Data

6. AUTHOR(S)

A. James Arnold and Robert E. Mickle

Forrest G. Hall and Karl Huemmrich, Editors

7. PERFORMING ORGANIZATION NAME(S) AND ADDRESS (ES)

Goddard Space Flight Center

Greenbelt, Maryland 20771

5. FUNDING NUMBERS

923

RTOP: $923-462-33-01$

9. SPONSORING / MONITORING AGENCY NAME(S) AND ADDRESS (ES)

10. SPONSORING / MONITORING AGENCY REPORT NUMBER

National Aeronautics and Space Administration

Washington, DC 20546-0001

TM-2000-209891

Vol. 194

\section{SUPPLEMENTARY NOTES}

A.J. Arnold and R.E. Mickle: Atmospheric Environment Service, Downsview, Ontario;

K. Huemmrich, University of Maryland, NASA Goddard Space Flight Center, Greenbelt, Maryland

\begin{tabular}{l|l}
\hline 12a. DISTRIBUTION / AVAILABILITY STATEMENT & 12b. DISTRIBUTION CODE \\
Unclassified-Unlimited & \\
Subject Category: 43 & \\
Report available from the NASA Center for AeroSpace Information, \\
7121 Standard Drive, Hanover, MD 21076-1320. (301) 621-0390.
\end{tabular}

13. ABSTRACT (Maximum 200 words)

The BOREAS TF-2 team collected meteorological and ozone measurements from instruments mounted below a tethered balloon. These data were collected at the SSA-OA site to extend meteorological and ozone measurements made from the flux tower to heights of $300 \mathrm{~m}$. The tethersonde operated during the fall of 1993 and the spring, summer, and fall of 1994 . The data are available in tabular ASCII files.

\begin{tabular}{|c|c|}
\hline $\begin{array}{l}\text { 14. SUBJECT TERMS } \\
\text { BOREAS, tower flux. }\end{array}$ & \\
\hline $\begin{array}{l}\text { 17. SECURITY CLASSIFICATION } \\
\text { OF REPORT } \\
\text { Unclassified }\end{array}$ & $\begin{array}{l}\text { 18. SECURITY CLASSIFICATION } \\
\text { OF THIS PAGE } \\
\text { Unclassified }\end{array}$ \\
\hline
\end{tabular}

19. SECURITY CLASSIFICATION OF ABSTRACT

Unclassified
15. NUMBER OF PAGES

13

16. PRICE CODE
20. LIMITATION OF ABSTRACT

UL 
